\title{
Development of temporary subtropical wetlands induces higher gas production
}

\author{
Eliete B. Canterle, David da Motta Marques* and Lúcia R. Rodrigues \\ Laboratório de Ecotecnologia e Limnologia, Instituto de Pesquisas Hidráulicas, Universidade Federal do Rio Grande do Sul, Porto Alegre, Brazil
}

\section{Edited by:}

André M. Amado, Universidade Federal do Rio Grande do Norte, Brazil

\section{Reviewed by:}

Susannah G. Tringe, DOE Joint Genome Institute, USA

Vinicius F. Farjalla, Universidade

Federal do Rio de Janeiro, Brazil

\section{*Correspondence.}

David da Motta Marques, Laboratório de Ecotecnologia e Limnologia, Instituto de Pesquisas Hidráulicas, Universidade Federal do Rio Grande do Sul, Avenida Bento Gonçalves 9500, Porto Alegre, RS 91501-970, Brazil. e-mail:dmm@iph.ufrgs.br
Temporary wetlands are short-term alternative ecosystems formed by flooding for irrigation of areas used for rice farming. The goal of this study is to describe the development cycle of rice fields as temporary wetlands in southern Brazil, evaluating how this process affect the gas production $\left(\mathrm{CH}_{4}\right.$ and $\left.\mathrm{CO}_{2}\right)$ in soil with difference \% carbon and organic matter content. Two areas adjacent to Lake Mangueira in southern Brazil were used during a rice-farming cycle. One area had soil containing $1.1 \%$ carbon and $2.4 \%$ organic matter, and the second area had soil with $2.4 \%$ carbon and $4.4 \%$ organic matter. The mean rates of gas production were $0.04 \pm 0.02 \mathrm{mg} \mathrm{CH}_{4} \mathrm{~m}^{-2} \mathrm{~d}^{-1}$ and $1.18 \pm 0.30 \mathrm{mg}$ $\mathrm{CO}_{2} \mathrm{~m}^{-2} \mathrm{~d}^{-1}$ in the soil area with the lower carbon content, and $0.02 \pm 0.03 \mathrm{mg} \mathrm{CH}_{4}$ $\mathrm{m}^{-2} \mathrm{~d}^{-1}$ and $1.38 \pm 0.41 \mathrm{mg} \mathrm{CO}_{2} \mathrm{~m}^{-2} \mathrm{~d}^{-1}$ in the soil area with higher carbon content. Our results showed that mean rates of $\mathrm{CO}_{2}$ production were higher than those of $\mathrm{CH}_{4}$ in both areas. No statistically significant difference was observed for production of $\mathrm{CH}_{4}$ considering different periods and sites. For carbon dioxide $\left(\mathrm{CO}_{2}\right)$, however, a Two-Way ANOVA showed statistically significant difference $(p=0.05)$ considering sampling time, but no difference between areas. The results obtained suggest that the carbon and organic matter contents in the soil of irrigated rice cultivation areas may have been used in different ways by soil microorganisms, leading to variations in $\mathrm{CH}_{4}$ and $\mathrm{CO}_{2}$ production.

Keywords: ecosystem development, $\%$ carbon, $\%$ organic matter, $\mathrm{CH}_{4}, \mathrm{CO}_{2}$

\section{INTRODUCTION}

Land use and land-use changes in agricultural and forest systems, industrial development, and urban expansion are among the sources of the current anthropogenic emissions of greenhouse gases (GHG) such as carbon dioxide $\left(\mathrm{CO}_{2}\right)$ and methane $\left(\mathrm{CH}_{4}\right)$. These activities have contributed to change the carbon and nitrogen cycles in terrestrial and aquatic ecosystems. Particularly, the contribution of agricultural soils to $\mathrm{CO}_{2}$ and $\mathrm{CH}_{4}$ emissions depends on biophysical processes and on the incorporation and decomposition of organic residues in the soil (Muñoz et al., 2010).

Wetlands, as well as rice paddies, contribute between 15 and $45 \%$ of global methane emissions (Segers, 1998). Organic matter tends to accumulate in the sediments of wetland soils. The carbon storage in soil organic matter is due to suppressed decomposition rates resulting from long-term soil saturation with water (Bohn et al., 2007). Soil organic matter is composed of a complex mixture of decayed plant and soil matter, with polymeric arrangements of these materials with other organic substrates (Wilson et al., 1983), whose rate and extent of degradation under either oxic and anoxic conditions are dependent on many biologic controls, including soil organic matter quality (Baldock and Skjemstad, 2000; Kristensen and Holmer, 2001; Blodau, 2002; Keller and Bridgham, 2007; Österreicher-Cunha et al., 2012).

The submerged conditions in rice paddies and the rice plants, especially their roots, supply the soil with organic carbon compounds which are mineralized by microorganisms (Hogberg and Read, 2006). The relationship between rice plants and microorganisms is important because the available substrates regulate many processes related to the emission or removal of gases (Insam and Wett, 2008).

Carbon gas production from wetland soil depends upon the rate of carbon deposition and the rate of mineralization (Smith et al., 2003). The rate of mineralization depends on a series of both biological and environmental factors and their interactions (Kristensen and Holmer, 2001). While the wetlands methane emissions result from anaerobic decomposition processes in deeper layers of wetland soil, $\mathrm{CO}_{2}$ emissions are related to oxidation of methane in upper oxic soil layers and respiration (Bohn et al., 2007). The rice-paddy sediment provides the ideal conditions for methanogenesis (Roehm, 2005), because the sediment undergoes oxygen depletion due to high moisture and relatively high organic-substrate levels and the presence of a methane-producing subsurface anaerobic zone and an aerobic surface zone that oxidizes this gas (Whalen, 2005). Anaerobic mineralization of carbon is the principal regulator of methane production in the sediment (Segers and Kengen, 1998), where the activity of methanogenic microorganisms converts a relatively narrow layer of simple substrates to methane (Zinder, 1998). Hence, the methanogenic microbial community in rice field soil contributes about $13 \%$ to the global budget of $\mathrm{CH}_{4}$ (Lelieveld et al., 1998). Other gases such as $\mathrm{CO}_{2}$ are also related to microbial activity.

Gas emissions from wetlands normally show wide seasonal and temporal fluctuations, resulting from variations in environmental variables that regulate the microbial processes involved in 
the flux (Liikanen et al., 2006). The main local controls of $\mathrm{CO}_{2}$ productions from wetlands include the quality of soil organic substrates (Updegraff et al., 1995). Given the diverse variables that control the emission of methane and other gases from wetland environments (Yang and Chang, 1998; van der Nat and Middelburg, 2000; Conrad, 2002; Hirota et al., 2004; Whalen, 2005; Liikanen et al., 2006; Cheng et al., 2007; Welsch and Yavitt, 2007; Kao-Kniffin et al., 2010; Khosa et al., 2010; Inubushi et al., 2011), evaluating these processes and the effects of participating microorganisms is a complex task.

Rice fields are temporary wetlands formed by the extensive irrigation of areas for periods of approximately 90 days, with long postproduction drainage periods. Available data concerning these temporary wetlands at latitudes above $30^{\circ}$ in the Southern hemisphere are sparse (Canterle et al., 2010; Rodrigues et al., 2011). Nevertheless, farming of irrigated rice represents the main crop for extensive lowland areas in southern Brazil, turning the soil of these areas in organic matter reservoirs, as the result of plant biomass accumulation at each production cycle. Considering that induced differences in the soil properties and microbiota characteristics may result in significant changes in the mineralization process, could rice fields, with different soil organic content and carbon, present different mineralization rates as measured by gas production? Therefore, the goal of this study is to describe the development cycle of rice fields as temporary wetlands, analyzing the dynamic of limnological variables and the mineralization process in the gas production $\left(\mathrm{CH}_{4}\right.$ and $\left.\mathrm{CO}_{2}\right)$ in areas with different incorporated organic matter and carbon content in southern Brazil.

\section{MATERIALS AND METHODS STUDY SITE}

The study was conducted during the 2005/2006 crop cycle in two areas of flooded-rice cultivation (BR-IRGA 410 cultivar). The water used to irrigate these areas was taken from Lake Mangueira (Figure 1) which, together with its contributing basin, form the Mangueira subsystem and cover an area of $1597 \mathrm{~km}^{2}$. This subsystem belongs to the Taim Hydrological

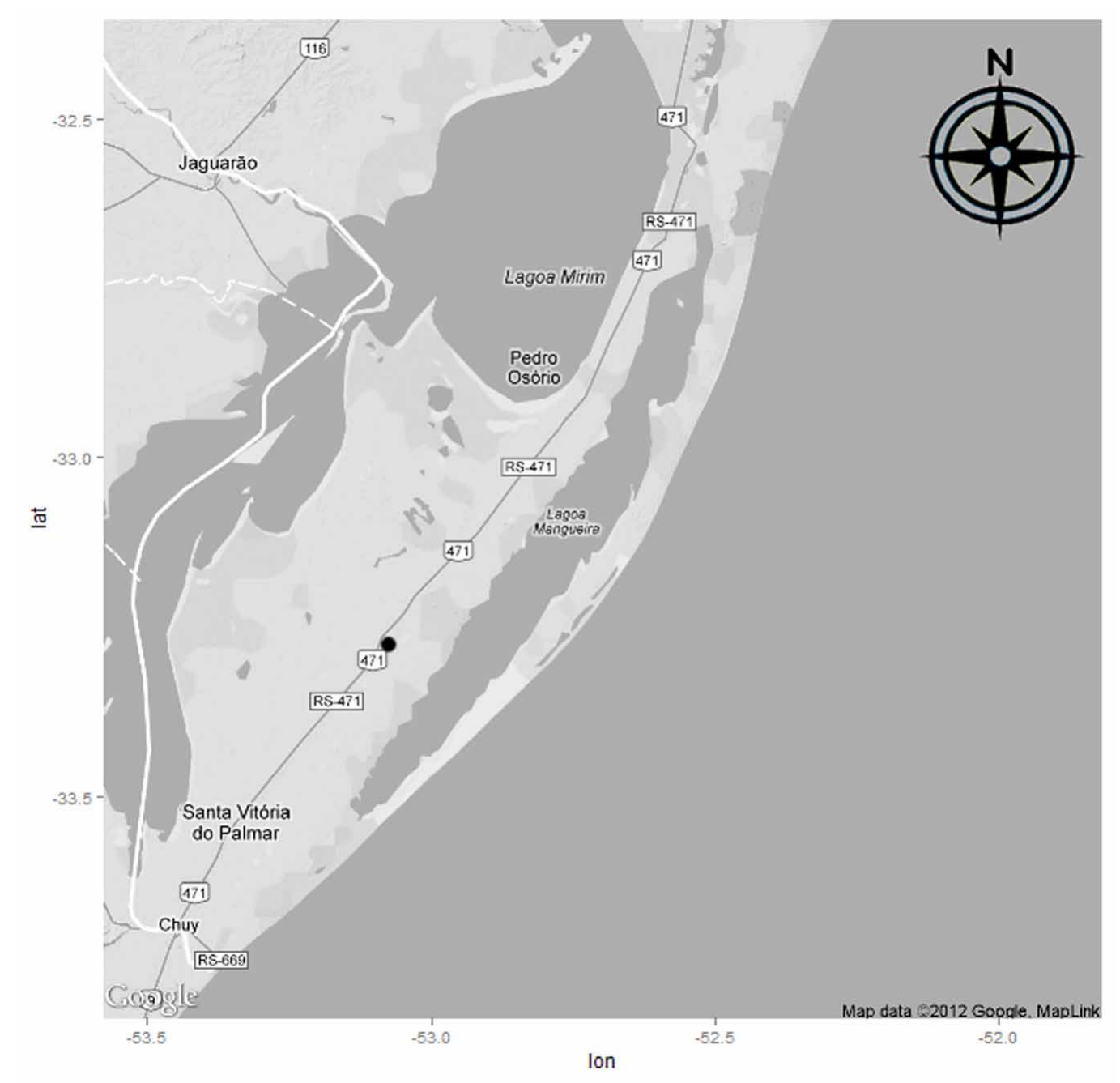

FIGURE 1 | Mangueira Lake, a large coastal lake in the state of Rio Grande do Sul, Southern Brazil, and localization of rice fields sampled (•). 
System and is part of a gradient of floodplains characterized by the presence of freshwater wetlands and associated lakes, situated in Rio Grande do Sul State in southern Brazil (MottaMarques et al., 2002). Part of the water used during irrigation of the cultivated areas returns to the lake via a drainage channel.

Each area has a soil with different organic-matter and carbon

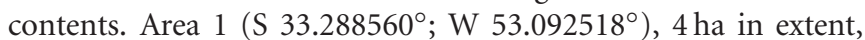
had soils with lower organic-matter and carbon contents. Area 2 $\left(\mathrm{S} 33.287297^{\circ}\right.$; W $53.088699^{\circ}$ ), with an area of 1 ha, had higher organic-matter and carbon contents.

\section{SAMPLING AND SAMPLE ANALYSIS}

Sampling was conducted between 16/12/2005 and 16/03/2006, corresponding to the rice crop cycle between the period of flooding (first week of December) and harvest (last week of March). Five sample series for each area were taken in order to estimate the production of gases and bacterial abundance (BA), and four sample series (except in the last sampling) were taken for limnological analyses.

Water samples were collected from the water/sediment interface at each sampling site for the limnological analysis. Water temperature, dissolved oxygen and $\mathrm{pH}$ were determined using a multiparameter probe (Yellow Springs Instruments model YSI 6920). Ten 1-L water samples were collected for chemical analysis and chlorophyll a. The variables were determined as follows: total phosphorous (TP), soluble reactive phosphorus (SRP), total nitrogen ( $\mathrm{TN})$, and nitrate (NO3) were analyzed according to Mackereth et al. (1989). Total solids (TS) were estimated according to APHA (1999), and soluble reactive silicon (SRSi) was measured by the photometric method, using a commercial kit (Si Merck Spectroquant7 kit for silicate-sulfuric acid). Dissolved organic matter (DOM) was analyzed by the spectrophotometric method (Strome and Miller, 1978). Carbon (dissolved organic, DOC; and dissolved inorganic, DIC) was analyzed using a total organic carbon (TOC) analyzer (Shimadzu VCPH). Chlorophyll a was extracted from GF/F filters in $90 \%$ ethanol (Jespersen and Christoffersen, 1987) and measured by the spectrophotometric method (APHA, 1999).

Sediment samples from each area were collected during the first sampling (December/05) for chemical, element and macronutrient analyses as the following methods: percentage of organic matter was determinate by humid digestion, clay was determinate by densimeter method, $\mathrm{K}$ and $\mathrm{P}$ were determinates by Mehlich I method, S-SO 4 extracted with $\mathrm{CaHPO}_{4} 500 \mathrm{mg} \mathrm{L}^{-1}$

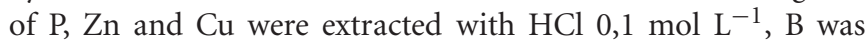
extracted with hot water, $\mathrm{Mn}$ exchangeable extracted with $\mathrm{KCl}$ $1 \mathrm{~mol} \mathrm{~L}^{-1}$ and \% soil carbon was analyzed using a TOC analyzer (Shimadzu VCPH).

For the $\mathrm{CH}_{4}$ and $\mathrm{CO}_{2}$ analysis, at five sites within each area, the surface layer (about $10 \mathrm{~cm}$ ) of the sediment was collected in PVC tubes, placed in plastic bags and stored in a refrigerator for no more than 2 days until incubation. At the sediment sampling sites, water samples from the water/sediment interface were collected in 50-mL flasks and also stored in the refrigerator until incubation was performed. In the laboratory, each sediment sample was homogenized and an aliquot of $6 \mathrm{~g}$ was placed in a $25-\mathrm{mL}$ glass flask and mixed with $5 \mathrm{~mL}$ of the water collected at the same site, forming five sludge slurry samples per area. Prior to incubation, gaseous nitrogen $\left(\mathrm{N}_{2}\right)$ was bubbled through the sludge slurry to create an anoxic environment (Minello, 2004). The flasks were closed with rubber septa, sealed with metal rings and incubated in the dark at a controlled temperature $\left(20 \pm 0.5^{\circ} \mathrm{C}\right)$. Gas production in the sediment was determined from the accumulation of $\mathrm{CH}_{4}$ and $\mathrm{CO}_{2}$ in the headspace of the incubation flasks (Casper, 1992). After a 5-d incubation period, an aliquot of the internal atmosphere of each flask was extracted to determine the $\mathrm{CH}_{4}$ and $\mathrm{CO}_{2}$ produced, using gas chromatography (Varian Star 3400 , Varian) with a flame ionization detector, injector temperature of $120^{\circ} \mathrm{C}$, a Chromosorb 102 column $\left(12^{\prime} \times 1 / 8^{\prime \prime}\right),(80 / 100)$ at $27^{\circ} \mathrm{C}$, and using helium as the carrier gas. Gas production, measured by gas chromatography, was expressed as $\mathrm{g}^{-1} \cdot \mathrm{L}^{-1}$. The data conversions were carried out using the mass $\times$ sediment volume relation (obtained from the PVC cores used in the removal of sediment samples and volume of the sediment). We assumed a fixed sediment depth for gas production considering values observed in the literature. Data conversion to $\mathrm{m}^{2}$ was done considering the core sampling area $\left(28.27 \mathrm{~cm}^{2}\right)$ and assuming that most of the gas production was related to the upper $10 \mathrm{~cm}$ of the sediment layer (Casper, 1992).

For bacterioplankton abundance analysis, water samples from the water-sediment interface at each sampling point were fixed in $40 \%$ formaldehyde (final concentration in the sample $=4 \%$ ) and prefiltered on quantitative paper (MN $640 \mathrm{~d}$ Macherey-Nagel; mean particle retention size $2.0-4.0 \mu \mathrm{m}$ ). Next, $2 \mathrm{ml}$ of each sample was filtered and stained with acridine orange, and cells were concentrated onto $0.2-\mu \mathrm{m}$ black polycarbonate membranes (GE), according to the modified protocol of Hobbie et al. (1977). BA, determined as cells per $\mathrm{mL}$, was estimated using an inverted epifluorescence microscope (Olympus IX70).

\section{DATA ANALYSIS}

Data analysis was performed by using a Two-Way ANOVA to compare gas production, BA and limnological variables. With this approach the two sites were compared after extracting the temporal effect, at the same time as sampling period were compared with no effect of sampling site. Associations between the different variables (gases, limnological variables and BA at the water/sediment interface) were assessed through correlation analyses using Spearman correlation coefficients. Statistical analyses were done using SigmaPlot 10.0 software. A probability level of $\alpha=0.05$ was adopted to determine statistical significance.

\section{RESULTS}

Analysis of soil from the sampling sites showed that the organicmatter, carbon and clay contents and $\mathrm{pH}$ were all higher in Area 2 than in Area 1 (Table 1). The percentages of organic matter and carbon in Area 1 sediment were approximately half those of Area 2. The mean $\mathrm{pH}$ values were also higher in Area 2. Regarding macronutrients, Area 1 showed a higher mean value for phosphorus, while higher mean values were obtained for potassium and manganese in Area 2.

The mean values for the limnological variables in both areas are presented in Table 2. During the study period, both rice fields 
Table 1 | Results of chemical analyses of soil from the sampling sites.

\begin{tabular}{lcc}
\hline Variable & Area 1 & Area 2 \\
\hline Organic matter (\%) & $2.4 \pm 0.2$ & $4.4 \pm 0.2$ \\
Carbon (\%) & $1.1 \pm 0.2$ & $2.4 \pm 0.6$ \\
Clay (\%) & $12.3 \pm 4.0$ & $15.7 \pm 3.1$ \\
$\mathrm{~K}(\%)$ & $148.7 \pm 60.4$ & $150.5 \pm 29.1$ \\
$\mathrm{P}(\%)$ & $25.3 \pm 10.8$ & $10.6 \pm 2.1$ \\
$\mathrm{Ca} / \mathrm{Mg}$ & $3.1 \pm 0.2$ & $4.7 \pm 2.0$ \\
$\mathrm{Ca} / \mathrm{K}$ & $6.6 \pm 1.6$ & $31 \pm 13.2$ \\
$\mathrm{Mg} / \mathrm{K}$ & $2.1 \pm 0.4$ & $6.7 \pm 1.5$ \\
$\mathrm{~S}(\%)$ & $9.5 \pm 2.7$ & $9.8 \pm 2.9$ \\
$\mathrm{Zn}(\%)$ & $2.3 \pm 1.2$ & $2.3 \pm 0.5$ \\
$\mathrm{Cu}(\%)$ & $1.3 \pm 0.3$ & $0.7 \pm 0.0$ \\
$\mathrm{~B}(\%)$ & $0.4 \pm 0.1$ & $0.5 \pm 0.1$ \\
$\mathrm{Mn}(\%)$ & $50.7 \pm 22.0$ & $6.3 \pm 0.6$ \\
$\mathrm{pH}$ & $5.6 \pm 0.2$ & $6.2 \pm 0.1$ \\
\hline
\end{tabular}

presented similar temperature and $\mathrm{pH}$. Mean concentrations of dissolved oxygen were higher in Area 1 than in Area 2. The concentrations of nutrients and chlorophyll $a$ showed a tendency to decrease over the course of the rice-crop cycle.

No statistically significant difference was observed for limnological variables between the areas. However, Two-Way ANOVA showed significant difference considering different periods in sites for DOC $(p=0.028)$; TS $(p=0.022)$; SRSi $(p=0.002)$; organic matter (UV-DOC $254 \mathrm{~nm})(p=0.024)$; chlorophyll $a$ $(p=0.000)$ and $\mathrm{NO}_{3}(p=0.020)$.

No statistically significant difference was observed for production of $\mathrm{CH}_{4}$ considering different periods and sites. Methane production (Figure 2) showed a general decreasing gradient during the rice-crop cycle for the samples from Area 1; however, the samples from Area 2 showed irregular production levels, once that was observed alternating higher or lower values for methane production over time, although higher production values have been registered in all samples (see standard deviation). The highest

Table 2 | Results of analyses of water from the water/sediment interface samples.

\begin{tabular}{|c|c|c|c|c|c|c|c|c|}
\hline Variable & \multicolumn{2}{|c|}{ Sampling 1} & \multicolumn{2}{|c|}{ Sampling 2} & \multicolumn{2}{|c|}{ Sampling 3} & \multicolumn{2}{|c|}{ Sampling 4} \\
\hline $\mathrm{DIC}\left(\mathrm{mg} \cdot \mathrm{L}^{-1}\right)$ & $19.66 \pm 4.4$ & $24.79 \pm 4.5$ & $21.82 \pm 2.3$ & $28.32 \pm 3.5$ & $25.47 \pm 2.5$ & $26.38 \pm 1.1$ & $27.74 \pm 2.8$ & $29.19 \pm 3.2$ \\
\hline $\mathrm{DOC}\left(\mathrm{mg} \cdot \mathrm{L}^{-1}\right)$ & $15.11 \pm 8.6$ & $18.33 \pm 10.6$ & $12.52 \pm 5.9$ & $10.16 \pm 2.7$ & $7.12 \pm 1.7$ & $6.33 \pm 0.8$ & $8.30 \pm 1.7$ & $7.42 \pm 1.9$ \\
\hline Total Solids (mg $\cdot \mathrm{L}^{-1}$ ) & $310 \pm 102$ & $274 \pm 96$ & $238 \pm 20$ & $247 \pm 12$ & $221 \pm 10$ & $211 \pm 11$ & $201 \pm 61$ & $201 \pm 17$ \\
\hline $\operatorname{SRSi}\left(\mathrm{mg} \cdot \mathrm{L}^{-1}\right)$ & $3.22 \pm 0.77$ & $3.47 \pm 0.68$ & $1.03 \pm 0.90$ & $1.56 \pm 1.04$ & $1.76 \pm 0.84$ & $2.14 \pm 0.48$ & $0.36 \pm 0.33$ & $0.27 \pm 0.09$ \\
\hline $\operatorname{TP}\left(\mu g \cdot L^{-1}\right)$ & $5.9 \pm 4.5$ & $3.2 \pm 1.9$ & $2.3 \pm 1.5$ & $2.8 \pm 1.7$ & $1.0 \pm 0.3$ & $1.5 \pm 0.2$ & $0.1 \pm 0.0$ & $0.1 \pm 0.0$ \\
\hline $\operatorname{SRP}\left(\mu \mathrm{g} \cdot \mathrm{L}^{-1}\right)$ & $2.82 \pm 2.31$ & $1.21 \pm 0.88$ & $0.30 \pm 0.38$ & $2.25 \pm 2.40$ & $0.14 \pm 0.03$ & $0.18 \pm 0.03$ & $0.03 \pm 0.02$ & $0.02 \pm 0.01$ \\
\hline $\mathrm{TN}\left(\mu \mathrm{g} \cdot \mathrm{L}^{-1}\right)$ & $100 \pm 20$ & $170 \pm 70$ & $40 \pm 20$ & $40 \pm 10$ & $30 \pm 20$ & $20 \pm 10$ & $20 \pm 10$ & $10 \pm 5$ \\
\hline $\mathrm{NO}_{3}-\mathrm{N}\left(\mu \mathrm{g} \cdot \mathrm{L}^{-1}\right)$ & $50 \pm 40$ & $50 \pm 20$ & $20 \pm 10$ & $30 \pm 20$ & $10 \pm 5$ & $10 \pm 5$ & NQ & NQ \\
\hline Dissolved oxygen $\left(\mathrm{mg} \cdot \mathrm{L}^{-1}\right)$ & 7.6 & 5.9 & 10.6 & 6.8 & 9.9 & 7.7 & 5.9 & 5.5 \\
\hline
\end{tabular}

DOM, dissolved organic matter; DIC, dissolved inorganic carbon; DOC, dissolved organic carbon; SRSi, soluble reactive silicate; TP, total phosphorus; SRP, soluble reactive phosphorus; $\mathrm{TN}$, total nitrogen; $\mathrm{NO}_{3}$, nitrate.

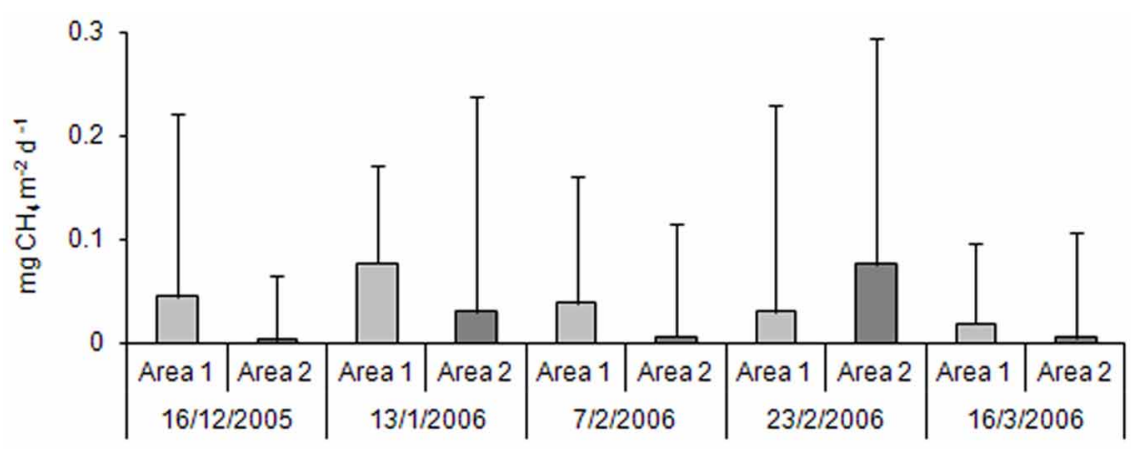

FIGURE 2 | Methane productions in the Area 1 and in the Area 2 throughout the rice crop cycle $(n=3)$. 
values were obtained in Area 1 in the second sampling, after the application of urea; in Area 2, the effect of application of the inorganic fertilizer probably resulted in higher values only in the third sampling.

For $\mathrm{CO}_{2}$, the highest values were observed in the third sampling, in both areas (Figure 3). A Two-Way ANOVA showed statistically significant difference $(p=0.05)$ considering sampling time, but no difference between areas.

Although the bacteria present in the sediment samples from the sampling sites, as well the attached bacteria have not been analyzed, unpublished data of the authors obtained in another study show an increase in density of methanogenic and methanotrophs microbial groups in experiments carried out with samples of the sediment-water interface. In addition, samples from the sediment-water interface site presents, normally, a consortium of microbes; it was added to the sludge slurry incubated in the experiment. These facts could be used to infer the effect of the microbial groups from the water/sediment interface samples in the gas production at the upper layer of sediment. Bacterioplankton abundance rates in the two areas showed similar trends as the values obtained for $\mathrm{CH}_{4}$ and $\mathrm{CO}_{2}$ production, with higher abundances in Area 1, which showed lower soil \% organic matter and \% carbon (Figure 4). The highest values for BA were observed in the second sampling, after the application of inorganic fertilizer in both areas.
A Two-Way ANOVA showed no statistically significant difference was observed for BA considering different periods and sites.

The correlation analysis of $\mathrm{CH}_{4}$ and $\mathrm{CO}_{2}$ production showed that gases in Area 1 were positively correlated with BA from the water/sediment interface samplings $\left(\mathrm{CH}_{4}: r=0.54 ; \mathrm{CO}_{2}: r=\right.$ 0.56 ; $p<0.05$ ). On the other hand, in Area 2 the $\mathrm{CH}_{4}$ production was not correlated with soil components or BA from the water/sediment interface samplings, while $\mathrm{CO}_{2}$ production was negatively correlated $(r=-0.60 ; p<0.05)$ with BA from the water/sediment interface.

From the data obtained in this study, it is possible to estimate the contribution of temporary subtropical wetlands in the region, regarding the production of $\mathrm{CH}_{4}$ and $\mathrm{CO}_{2}$ gases. Considering the mean rates of gases production in the two areas $(n=5)$, mean methane production was $0.041 \pm 0.02 \mathrm{mg} \mathrm{m}^{-2} \mathrm{~d}^{-1}$ in Area 1 and $0.024 \pm 0.03 \mathrm{mg} \mathrm{m}^{-2} \mathrm{~d}^{-1}$ in Area 2, while the mean production rate for $\mathrm{CO}_{2}$ production presented $1.178 \pm 0.3 \mathrm{mg} \mathrm{m}^{-2} \mathrm{~d}^{-1}$ in Area 1 and $1.383 \pm 0.41 \mathrm{mg} \mathrm{m}^{-2} \mathrm{~d}^{-1}$ in Area 2. The difference in mean values was not statistically significant.

When compared the values obtained for the gas production rates obtained in this study with the rates obtained in studies carried out in different environments and countries, can observe that our rates showed lower values (Table 3). According to the table, the lowest values of methane production were observed in studies

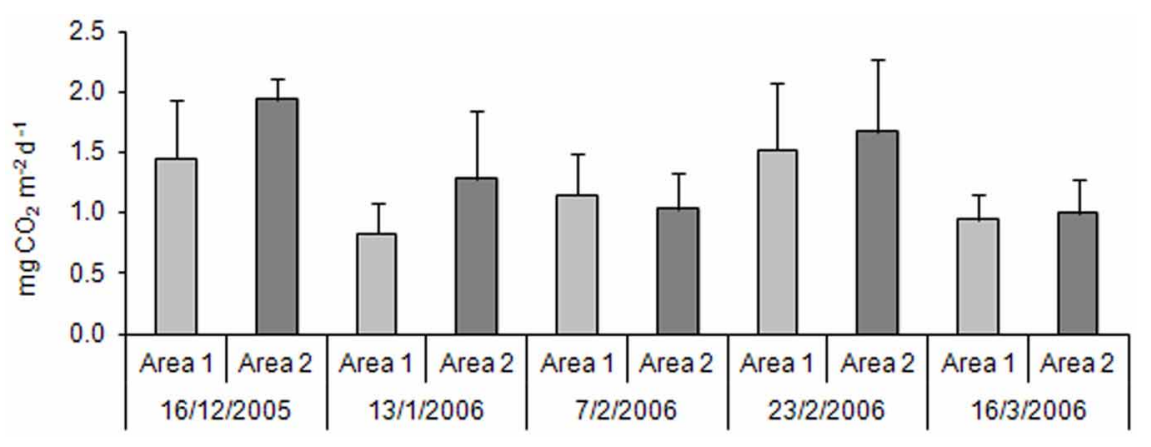

FIGURE 3 | Carbon dioxide productions in the Area 1 and in the Area 2 throughout the rice crop cycle $(n=3)$.

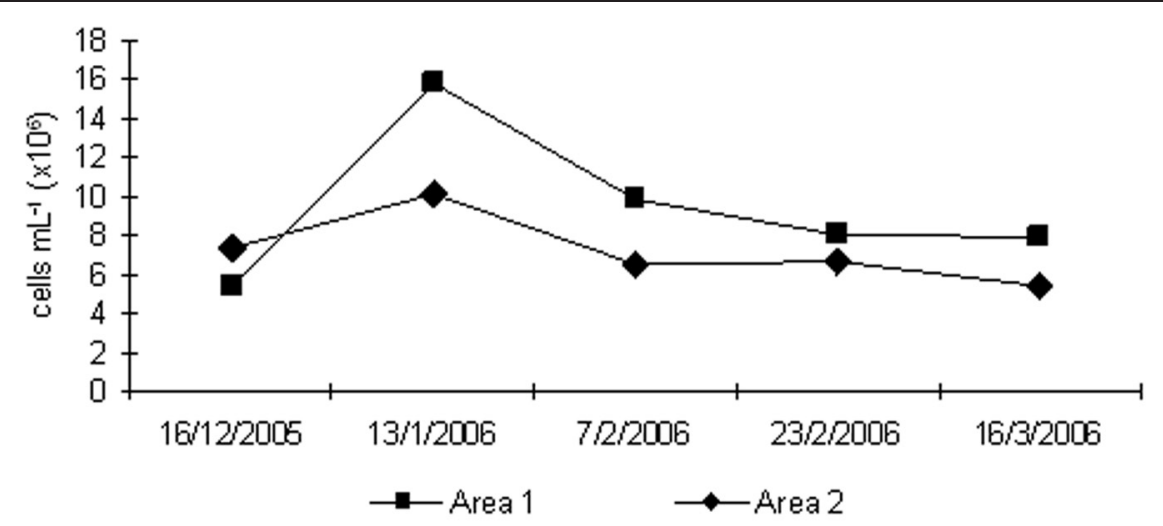

FIGURE 4 | Bacterioplankton abundance rates obtained from the water/sediment interface in both areas during rice cultivation. 
Table 3 | Rates of $\mathrm{CH}_{4}$ and $\mathrm{CO}_{2}$ production in soils intermittent or permanently inundated.

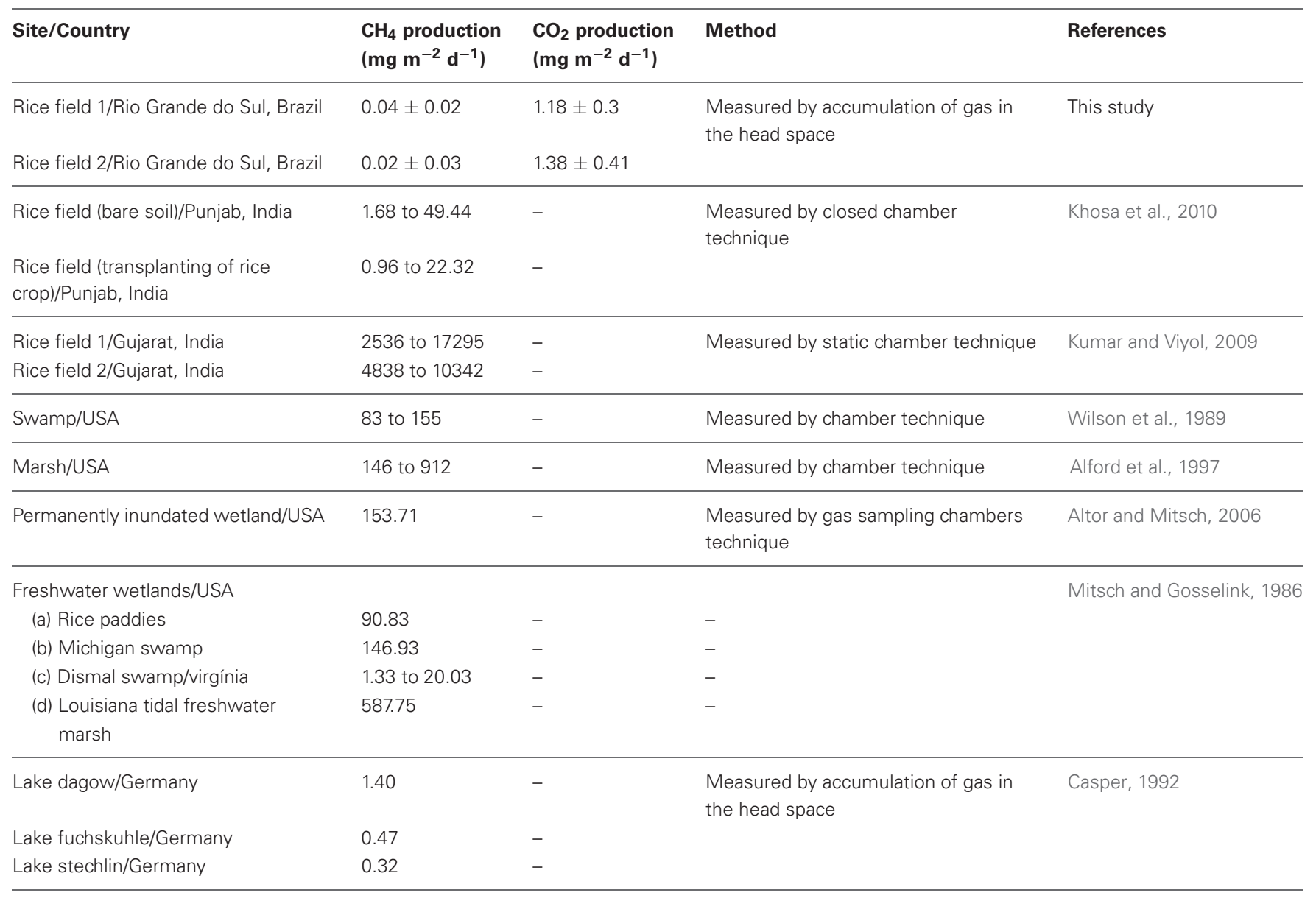

that use such methodology measurement of accumulation of gas in the head space.

\section{DISCUSSION}

In this study we found higher $\mathrm{CO}_{2}$ production in Area 2 than Area 1 , associated with higher carbon and organic-matter contents in the soil. Moreover, there was significant difference concerning sampling time, but no difference between areas. The overall $\mathrm{CH}_{4}$ production as well as the BA obtained from water/sediment interface sampling did not differ significantly between the areas and sampling time.

Organic-carbon content parallels the rate of methane emission in rice fields (Kumar and Viyol, 2009). Differences in the organic chemistry of a specific soil type (Yavitt and Lang, 1990) and in the composition of the organic matter between environments, whether they are more labile or more refractory, influence mineralization $\left(\mathrm{CO}_{2}\right.$ and $\mathrm{CH}_{4}$ formation) in the presence or absence of oxygen (Bastviken et al., 2003), resulting in variations in methane production rates between different wetland samples (Yavitt and Lang, 1990). Soil characteristics and microbiota, associated with other factors, and could result in different responses related to availability and carbon cycling (Österreicher-Cunha et al., 2012). The observed differences in the soil composition of the two areas used in this study, related to the \% carbon and organic matter content, should be result in diverse responses to gas production in the samplings carried out over the cycle of rice crops.

The structure of the soil bacterial community, although it was not evaluated, was probably important for the gas emissions observed in this study. The numbers of methanogenic and methanotrophic bacteria as well as the type of methanotrophic bacteria affect $\mathrm{CH}_{4}$ production (Wang et al., 2008). However, according to Krüger et al. (2005), observed variations in methanogenic processes are probably not caused by changes in the size of the methanogen community but in its activity. Observations on the pathway of $\mathrm{CH}_{4}$ formation showed that substrate conditions most affect the methanogen community structure and function (Chin et al., 2004). The highest rates of methane and carbon-dioxide production, as well as microbial abundance from water-sediment interface samples occurred until the third sampling, before the rice plants had attained their maximum biomass (at the end of the culture cycle) in both areas. Although a number of environmental controls over bacterial respiration have been studied in wetlands (Segers, 1998), this fact implies that, probably, the differences in soil organic matter, rather than plant growth, drive most of the microbial activity, in concordance with results obtained by Welsch and Yavitt (2007). The different effects of organic matter may be closely related to the content of easily decomposable organic matter (Hou et al., 2000), 
as well as the release of more-labile substrates that can be more easily assimilated by the microorganisms present in the water and sediment surface layers (Fonseca et al., 2004). Otherwise, the continuum of decomposability of the organic matter in soil can be altered by interactions with minerals within matrices capable of stabilizing potentially labile organic matter against biological oxidation (Baldock and Skjemstad, 2000), producing changes in the organic matter mineralization processes present in the soil of different areas. These variables probably influenced the methane production rates especially in Area l, even taking into account the differences in organic-matter concentrations.

The relationships between plants and soil microorganisms are important for bacterial activity (Hogberg and Read, 2006), and indirectly affect gas production. Methanotrophs are a diverse group of aerobic bacteria mainly found on the rhizosphere of aquatic plants, and their growth is favored by this aerobic microsite in the process of $\mathrm{CH}_{4}$ consumption (Wang et al., 2008). Increased soil carbon contents often stimulate microbial growth and activity, which can increase the availability of soil nutrients and enhance plant growth (Weihong et al., 2000). The presence and the different species of macrophytes generally reduce GHG fluxes, due to a significant impact on oxygen dynamics, mainly via their capacity to increase redox potentials and dissolved oxygen concentration (Maltais-Landry et al., 2009). According to Bouchard et al. (2007), rapid root production and increased rooting depth enhance $\mathrm{CH}_{4}$ oxidation to a relatively greater degree than methane production.

In this study, methane concentrations showed a decreasing gradient in successive samplings, especially in Area 1, in contrast to plant growth. The plant growth stage can affect the production of gases considering the development of underground biomass, and potential loss or GHG though leaves. The reduction in the methane concentrations observed as the cultivation cycle evolved could be an effect of plant and root development, substantially, or totally inhibiting methane production (Gilbert and Frenzel, 1998) and producing the irregular values obtained in this study. These results are in agreement with those of Picek et al. (2007), once that they found a gradual decline in both $\mathrm{CH}_{4}$ and $\mathrm{CO}_{2}$ toward the end of the growing season. The plants could attenuate methane emission, facilitating its oxidation by the transport and release of oxygen through the roots located in the aerobic surface zone of the sediment (Schrope et al., 1999; Whalen, 2005). However, measurements of growth of the rice were not performed throughout the cycle, which needs to be stated as a variable to be considered in the follow up works.

Permanently flooded areas produce more methane than those that are intermittently flooded (Kumar and Viyol, 2009), with or without the presence of emerging macrophytes (Altor and Mitsch, 2006). Variations in the water level can affect the emission of gases such as methane and $\mathrm{CO}_{2}$ (Ratering and Conrad, 1998; Cheng et al., 2007; Hirota et al., 2007). In this study, the first sampling conducted in Area 2 resulted in the lowest methane production level of the entire cultivation cycle, when the areas reached minimal water layers. The drainage of the rice paddies resulted in decreased methane production, since this would increase the penetration of oxygen into the soil and suppress the production of this gas. On the other hand, the aeration process can result in an increase of $\mathrm{CO}_{2}$ production, since that the degradation of organic matter is more efficient under oxidized conditions (Ratering and Conrad, 1998). Oxygen penetration into the soil permits oxidation of reduced sulfur to sulfate and ferrous iron to ferric iron. Sulfate and iron (III) favor the action of sulfur- and iron-reducing bacteria that use acetate and hydrogen substrates more efficiently than methanogenic bacteria (Ratering and Conrad, 1998). These processes lead to competition for the substrates, as observed by Minello (2004) in a study conducted on lagoon sediment, and, consequently, the hydrogen and acetate concentrations drop to levels that prohibit methane production (Ratering and Conrad, 1998; Conrad, 2002).

Under anaerobic conditions, the mineralization of organic carbon to $\mathrm{CO}_{2}$ and $\mathrm{CH}_{4}$ is carried out by a consortium of microbes, where the complex organic polymers are initially degraded by fermenting bacteria to yield a few simple products, which are subsequently used by methanogens to produce $\mathrm{CH}_{4}$ (Conrad, 1989). The relative proportion in which $\mathrm{CO}_{2}$ and methane gases are produced from organic material depends on the presence of sufficient inorganic oxidants, such as nitrate, manganese (IV), iron (III) and sulfate. When this is the case, the organic material is principally degraded to $\mathrm{CO}_{2}$, increasing its production, and relatively little methane is produced (Yao and Conrad, 2000; Krüger et al., 2001). Our results showed that the mean rates of $\mathrm{CO}_{2}$ production were higher than those of $\mathrm{CH}_{4}$ in both areas. These results are also in agreement with those of Picek et al. (2007), who found that only $10 \%$ of the total carbon emissions from a constructed wetland were in the form of $\mathrm{CH}_{4}$; and with Bastviken et al. (2003), who measured the mineralization of organic carbon in oxic and anoxic lake sediments and found that carbon-dioxide production dominated that of methane as a mineralization product. Also, the lower temperatures used in the incubations, closer to the value that is best suited for $\mathrm{CO}_{2}$ production, as well as variables such as the products originating from the breakdown of organic matter, increase the likelihood of more efficient use of the exudates released by the organic matter throughout cultivation (Silvola et al., 1996) and explain the higher production of $\mathrm{CO}_{2}$ than methane, as seen in the results obtained in the two cultivated areas.

The combination of low soil $\mathrm{pH}$ and potential methanotrophy, together with the addition of fertilizer, may have caused a low methane production in this temporary wetland. During the crop cycle of the rice paddies, two applications of urea fertilizer were made in both areas, during the initial phase of cultivation. Whereas Krüger and Frenzel (2003) observed little to no change in overall $\mathrm{CH}_{4}$ emissions from rice fields in response to increased $\mathrm{N}$-fertilization, other studies have found variable effects. The application of fertilizers could lead to a reduction rather than an increase in methane emission in wetlands formed by rice fields (Bodelier et al., 2000a). Urea increases soil pH and reduces methane production, especially when it is incorporated at some depth, since the majority of methane-producing organisms are neutrophilic and their production slows at $\mathrm{pH}$ values lower than 6.4 and higher than 7.8 (Wang et al., 1992). Also, the effect of fertilization stimulates the activity of methanotrophic organisms, controlling the emission of methane close to the plants, thus reducing its emission (Bodelier et al., 2000b). 
The present study shows lower values compared with the data obtained in studies performed in other ecosystems, such as rice fields and wetlands of the Northern hemisphere. The lowest values of methane production were observed in studies that use such methodology measurement of accumulation of gas in the head space. However, comparison of rates of methane production from different studies is very difficult, since many variables such as environmental factors need to be considered in the analysis of gas production rates. In addition to these factors, different methods are used and the rates are dependent on both temperature and hydroperiod (Mitsch and Gosselink, 1986), which may result in variations in the data, hindering the analysis and interpretation of results.

The results obtained in this study suggest that the carbon and organic-matter contents in the soil of irrigated rice cultivation areas may have been used in different ways by

\section{REFERENCES}

Alford, D. P., Delaune, R. D., and Lindau, C. W. (1997). Methane flux from Mississipi River deltaic plain wetlands. Biogeochemistry 37, 227-236.

Altor, A. N., and Mitsch, W. J. (2006). Methane flux from created riparian marshes: relationship to intermittent versus continuous inundation and emergent macrophytes. Ecol. Eng. 28, 224-234.

APHA. (1999). American Public Health Association: American Water Association: Water Environmental Federation: Standard Methods for the Examination of Water and Wastewater. 20th Edn. Washington, DC: American Public Health Association.

Baldock, J. A., and Skjemstad, J. O. (2000). Role of the soil matrix and minerals in protecting natural organic materials against biological attack. Org. Geochem. 31, 697-710.

Bastviken, D., Olsson, M., and Tranvik, L. (2003). Simultaneous measurements of organic mineralization and bacterial production in oxic and anoxic lake sediments. Microb. Ecol. $46,73-82$.

Blodau, C. (2002). Carbon cycling in peatlands-A review of processes and controls. Environ. Rev. 10, 111-134.

Bodelier, P. L. E., Roslev, P., Henkel, T., and Frenzel, P. (2000a). Stimulation by ammonium-based fertilizers of methane oxidation in soil around rice roots. Nature 403, 421-424.

Bodelier, P. L. E., Hahn, A. P., Arth, I. R., and Frenzel, P. (2000b). Effects of ammonium-based fertilization on microbial processes involved in methane emission from soil planted with rice. Biogeochemistry 51, 225-257.

Bohn, T. J., Lettenmaier, D. P., Sathulur, McDonald, K. C., et al. (2007). Methane emissions from western Siberian wetlands: heterogeneity and sensitivity to climate change. Environ. Res. Lett. 2, 1-9.

Bouchard, V., Frey, S. D., Gilbert, J. M., and Reed, S. E. (2007). Effects of macrophyte functional group richness on emergent freshwater wetland functions. Ecology 88, 2903-2914.

Canterle, E. R. B., Rodrigues, L. H. R., Hamester, A., and Motta Marques, D. (2010). Produção de Gases de Efeito Estufa $\left(\mathrm{CH}_{4}\right.$ e $\mathrm{CO}_{2}$ ) em Banhados Temporários Subtropicais. Rev. Bras. Recurs. Hídric. 15, 161-171.

Casper, P. (1992). Methane production in lakes of different trophic state. Arch. Hydrobiol. Beih. Ergebn. Limnol. 37, 149-154.

Cheng, X., Peng, R., Chen, J., Luo, Y., Zhang, Q., An, S., et al. (2007). $\mathrm{CH}_{4}$ and $\mathrm{N}_{2} \mathrm{O}$ emissions from Spartina alterniflora and Phragmites australis in experimental mesocosms. Chemosphere 68, 420-427. M. W., Klose, M., and Conrad, R. (2004). Archaeal community structure and pathway of methane formation on rice roots. Microb. Ecol. 47, 59-67.

Conrad, R. (1989). "Control of methane production in terrestrial ecosystems," in Exchange of Trace Gases between Ecosystems and the Atmosphere, eds M. O. Andreae and D. S. Schimel (New York, NY: John Wiley and Sons), 39-58. K., Bowling, L. C., Podest, E.,

Chin, K. J., Lueders, T., Friedrich,

soil microorganisms, leading to variations in $\mathrm{CH}_{4}$ and $\mathrm{CO}_{2}$ production. Identifying the conditions in which these processes occur and the types of organisms involved would help explain the variation observed in this and other studies. Our data suggest that differences between ecosystems, such as the carbon and organic matter content presents in temporary wetlands soil, could result in variations of $\mathrm{CH}_{4}$ and $\mathrm{CO}_{2}$ production rates even for limited periods of time.

\section{ACKNOWLEDGMENTS}

The authors draw particular attention to the assistance provided by the Chico Mendes Institute of Biodiversity (ICM-Bio-ESEC TAIM). Financial support was provided by the Conselho Nacional de Desenvolvimento Científico e Tecnológico under the Brazilian Network of Long-Term Ecological Research sites, Site 7, Sistema Hidrológico do Taim. We are also grateful to Dr. Janet W. Reid (JWR Associates) for revising the English text.

Conrad, R. (2002). Control of microbial methane production in wetland rice fields. Nutr. Cycling Agroecosyst. 64, 59-69.

Fonseca, A. L. S., Minello, M., Marinho, C. C., and Esteves, F. A. (2004). Methane concentration in water column and in pore water of a coastal lagoon (Cabiúnas lagoon, Macaé, RJ, Brazil). Braz. Arch. Biol. Techol. 47, 301-308.

Gilbert, B., and Frenzel, P. (1998). Rice roots and $\mathrm{CH}_{4}$ oxidation: the activity of bacteria, their distribution and the microenvironment. Soil Biol. Biochem. 30, 1903-1916.

Hirota, M., Senga, Y., Seike, Y., Nohara, S., and Kunii, H. (2007). Fluxes of carbon dioxide, methane and nitrous oxide in two contrastive fringins zones of coastal lagoon, Lake Nakaumi, Japan. Chemosphere 68, 597-603.

Hirota, M., Tang, Y., Hu, Q., Hirata, S., Kato, T., Mo, W., et al. (2004). Methane emissions from different vegetation zones in a QinghaiTibetan Plateau wetland. Soil Biol. Biochem. 36, 737-748.

Hobbie, J. E., Daley, R. J., and Jasper, S. (1977). Use of Nuclepore filters for counting bacteria by fluorescence microscopy. Appl. Environ. Microbiol. 33, 1225-1228.

Hogberg, P., and Read, D. J. (2006). Towards a more plant physiological perspective on soil ecology. Trends Ecol. Evol. 21, 548-554.

Hou, A. X., Wang, Z. P., Chen, G. X., and Patrick, W. H. (2000). Effects of organic and $\mathrm{N}$ fertilizers on methane production potential in a Chinese rice soil and its microbiological aspect. Nutr. Cycling Agroecosyst. 58, 333-338.
Insam, H., and Wett, B. (2008). Control of GHG emission at the microbial community level. Waste Manag. 28, 699-706.

Inubushi, K., Cheng, W., Mizuno, T., Lou, Y., Hasegawa, T., Sakai, H., et al. (2011). Microbial biomass carbon and methane oxidation influenced by rice cultivars and elevated $\mathrm{CO}_{2}$ in a Japanese paddy soil. Eur. J. Soil Sci. 62, 69-73.

Jespersen, A. M., and Christoffersen, K. (1987). Measurements of chlorophyll-a from phytoplankton using ethanol as extraction solvent. Arch. Hydrobiol. 109, 445-454.

Kao-Kniffin, J., Freyre, D. S., and Balser, T. C. (2010). Methane dynamics across wetland plant species. Aquat. Bot. 93, 107-113.

Keller, J. K., and Bridgham, S. D. (2007). Pathways of anaerobic carbon cycling across an ombrotrophic-minetrophic peatland gradient. Limnol. Oceanogr. 52, 96-107.

Khosa, K. M., Sidhu, B. S., and Benbi, D. K. (2010). Effect of organic materials and rice cultivars on methane emission from rice field. J. Environ. Ecol. 31, 281-285.

Kristensen, E., and Holmer, M. (2001). Decomposition of plant materials in marine sediment exposed to different electron acceptors $\left(\mathrm{O}_{2}\right.$, $\mathrm{NO}_{3}^{-}$, and $\mathrm{SO}_{4}^{2-}$ ), with enphasis on substrate origin, degradation kinetics, and the role of bioturbation. Geochim. Cosmochim. Acta 65, 419-433.

Krüger, M., and Frenzel, P. (2003). Effects of $\mathrm{N}$-fertilization on $\mathrm{CH}_{4}$ oxidation and production, and consequences for $\mathrm{CH}_{4}$ emissions from microcosms and rice fields. Glob. Change Biol. 9, 773-784. 
Krüger, M., Frenzel, P., and Conrad, R. (2001). Microbial processes influencing methane emission from rice fields. Glob. Change Biol. 7, 49-63.

Krüger, M., Frenzel, P., Kemnitz, D., and Conrad, R. (2005). Activity, structure and dynamics of the methanogenic archaeal community in a flooded Italian rice field. FEMS Microb. Ecol. 51, 323-331.

Kumar, J. I. N., and Viyol, S. (2009). Short term diurnal and temporal measurement of methane emission in relation to organic carbon, phosphate and sulphate content of two rice fields of central Gujarat, India. J. Environ. Biol. 30, 241-246.

Lelieveld, J., Crutzen, P. J., and Dentener, F. J. (1998). Changing concentrations, lifetime and climate forcing of atmospheric methane. Tellus 50B, 128-150.

Liikanen, A., Huttunen, J. T., Karjalainen, S. M., Heikkinen, K., Väisänen, T. S., Nykänen, H., et al. (2006). Temporal and seasonal changes in greenhouse gas emissions from a constructed wetland purifying peat mining runoff waters. Ecol. Eng. 26, 241-251.

Mackereth, F. J. H., Heron, J., and Talling, J. F. (1989). Water Analysis: Some Revised Methods for Limnologists. 2nd Edn. Ambleside: Freshwater Biological Association.

Maltais-Landry, G., Maranger, R., and Brisson, J. (2009). Effect of artificial aeration and macrophyte species on nitrogen cycling and gas flux in constructed wetlands. Ecol. Eng. 35, 221-229.

Minello, M. (2004). Metanogênese sob a variação de salinidade em lagoas costeiras do norte do estado do Rio de Janeiro (Brasil): Implicações nas condições osmóticas e na competição por substratos. Dissertação. UFRJ, RJ, Brazil.

Mitsch, W. J., and Gosselink, J. G. (1986). Wetlands. New York, NY: Van Nostrand Reinhold.

Motta-Marques, D., Tucci, C., Calazans, D., Callegaro, V. L. M., and Villanueva, A. (2002). "O Sistema Hidrológico do Taim, Site 7," in Os Sites e o Programa Brasileiro de Pesquisas Ecológicas de Longa Duração, eds U. Seeliger, C. Cordazzo, and F. Barbosa
(Belo Horizonte: FURG/UFMG), 125-144.

Muñoz, C., Paulino, L., Monreal, C., and Zagal1, E. (2010). Greenhouse gas $\left(\mathrm{CO}_{2}\right.$ and $\left.\mathrm{N}_{2} \mathrm{O}\right)$ emissions from soils: a review. Chilean J. Agric. Res. 70, 485-497.

Österreicher-Cunha, P., Vargas, E. A. Jr., Antunes, F. S., Mothé, G. P. B., Guimarães, J. R. D., and Coutinho, H. L. C. (2012). Influence of soil and climate on carbon cycling and microbial activity of a heterogeneous tropical soil. Geomicrobiol. J. 29, 399-412.

Picek, T., Čížková, H., and Dušek, J. (2007). Greenhouse gas emissions from a constructed wetland - Plants as important sources of carbon. Ecol. Eng. 31, 98-106.

Ratering, S., and Conrad, R. (1998). Effects of short-term drainage and aeration on the production of methane in submerged rice soil. Glob. Change Biol. 4, 397-407.

Rodrigues, L. H. R., Canterle, E. B., Becker, V., Gazulha, V., Hamester, A., and Motta Marques, D. (2011). Dynamics of plankton and fish in a subtropical temporary wetland: rice fields. Sci. Res. Essays 6, 2069-2077.

Roehm, C. L. (2005). "Respiration in wetland ecosystems," in Respiration in Aquatic Ecosystems, eds P. A. del Giorgio and P. J. Williams (New York, NY: Oxford University Press), 83-102.

Schrope, M. K., Chanton, J. P., Allen, L. H., and Baker, J. T. (1999). Effect of $\mathrm{CO}_{2}$ enrichment and elevated temperature on methane emissions from rice, Oryza sativa. Glob. Change Biol. 5, 587-599.

Segers, R. (1998). Methane production and methane consumption: a review of processes underlying wetland methane fluxes. Biogeochemistry 41, 23-51.

Segers, R., and Kengen, W. M. (1998). Methane production as a function of anaerobic carbon mineralization: a process model. Soil Biol. Biochem. 30, 1107-1117.

Silvola, J., Alm, J., Ahlholm, U., Nykänen, H., and Martikainen, P. J. (1996). The contribution of plant roots to $\mathrm{CO}_{2}$ fluxes from organic soils. Biol. Fertil. Soils 23, 126-131.
Smith, K. A., Ball, T., Conen, F., Dobbie, K. E., Massheder, J., and Rey, A. (2003). Exchange of greenhouse gases between soil and atmosphere: interactions of soil physical factors and biological processes. Eur. J. Soil Sci. 54, 779-791.

Strome, D. J., and Miller, M. C. (1978). Photolytic changes in dissolved humic substances. Ver. Int Verein. Theoret Angew Limnol. 20, 1248-1254.

Updegraff, K., Pastor, J., Bridgham, S. D., and Johnston, C. A. (1995) Environmental and substrate controls over carbon and nitrogen mineralization in northern wetlands. Ecol. Appl. 5, 151-163.

van der Nat, F.-J. W. A., and Middelburg, J. J. (2000). Methane emission from tidal freshwater marshes. Biogeochemistry 49, 103-121.

Wang, Y., Inamori, R., Kong, H., Xu, K., Inamori, Y., Kondo, T., et al. (2008). Influence of plant species and wastewater strength on constructed wetland methane emissions and associated microbial populations. Ecol. Eng. 32, 22-29.

Wang, Z. P., Delaune, R. D., Lindau, C. W., and Patrick, W. H. (1992) Methane production from anaerobic soil amended with rice straw and nitrogen fertilizers. Fertil. Res. 33, 115-121.

Weihong, L., Fusuo, Z., and Kezhi, B. (2000). Responses of plant rhizosphere to atmospheric $\mathrm{CO}_{2}$ enrichment. Chin. Sci. Bull. 45, 97-101.

Welsch, M., and Yavitt, J. B. (2007). Microbial $\mathrm{CO}_{2}$ production, $\mathrm{CH}_{4}$ dynamics and nitrogen in a wetland soil (New York State, USA) associated with three plant species (Typha, Lythrum, Phalaris). Eur. J. Soil Sci. 58, 1493-1505.

Whalen, S. C. (2005). Biogeochemistry of methane exchange between natural wetlands and the atmosphere. Environ. Eng. Sci. 22, 73-94.

Wilson, J. O., Crill, P. M., Bartlett, K. B., Sebacher, D. I., Hariss, R. C., and Sass, R. L. (1989). Seasonal variation of methane emissions from a temperate swamp. Biogeochemistry 8, 55-71.

Wilson, M., Philp, R., Gillam, A., Gilbert, T., and Tate, K. (1983).
Comparison of the structures of humic substances from aquatic and terrestrial sources by pyrolysis gas chromatography mass spectrometry. Geochim. Cosmochim. Acta 4, 497-502.

Yang, S.-S., and Chang, H.-L. (1998). Effect of environmental conditions on methane production and emission from paddy soil. Agric. Ecosyst. Environ. 69, 69-80.

Yao, H., and Conrad, R. (2000). Electron balance during steadystate production of $\mathrm{CH}_{4}$ and $\mathrm{CO}_{2}$ in anoxic rice soil. Eur. J. Soil Sci. 51, 369-378.

Yavitt, J. B., and Lang, G. E. (1990). Methane production in contrasting wetland sites - response to organicchemical components of peat and to sulfate reduction. Geomicrobiol. J. 8, 27-46.

Zinder, S. (1998). "Methanogens," in Techniques in Microbial Ecology, eds R. S. Burlage, R. Atlas, D. Stahl, G. Geesey, and G. Sayler (New York, NY: Oxford University Press), 113-123.

Conflict of Interest Statement: The authors declare that the research was conducted in the absence of any commercial or financial relationships that could be construed as a potential conflict of interest.

Received: 30 August 2012; accepted: 26 February 2013; published online: 15 March 2013.

Citation: Canterle EB, Motta Marques D and Rodrigues LR (2013) Development of temporary subtropical wetlands induces higher gas production. Front. Microbiol. 4:56. doi: 10.3389/fmicb. 2013.00056

This article was submitted to Frontiers in Aquatic Microbiology, a specialty of Frontiers in Microbiology.

Copyright (c) 2013 Canterle, Motta Marques and Rodrigues. This is an openaccess article distributed under the terms of the Creative Commons Attribution License, which permits use, distribution and reproduction in other forums, provided the original authors and source are credited and subject to any copyright notices concerning any third-party graphics etc. 